Jpn. J. Med. Sci. Biol., 50, 63 - 71, 1997.

\title{
DISCRIMINATION OF LISTERIA MONOCYTOGENES STRAINS OF SEROTYPE 4b BY RESTRICTION ENZYME ANALYSIS OF CHROMO- SOMAL DNA
}

\author{
Akinobu SAITO, Takuo SAWADA1, Yoshikazu TOKUMARU \\ and Ryo $\mathrm{HONDO}^{2}$
}

Division of Food Hygiene, Saitama Institute of Public Health, 639-1, Kamiokubo, Urawa-shi, Saitama 338, 1Department of Veterinary Microbiology and 2Department of Veterinary Public Health, Nippon Veterinary and Animal Science Univeristy, 1-7-1 Kyonan-cho, Musashino-shi, Tokyo 180

(Received December 26, 1997. Accepted March 21, 1997)

SUMMARY: Epidemiologically related cheese and environmental strains and epidemiologically unrelated strains of Listeria monocytogenes serotype $4 \mathrm{~b}$ were examined by restriction enzyme analysis of chromosomal DNA with a total of 10 restriction enzymes. The DNA fingerprint patterns generated from each restriction enzyme digest of total DNA of all strains were classified. The restriction enzyme patterns of seven strains recovered from cheese and environmental samples in the same plant were identical to each other, but differed from those of seven epidemiologically unrelated strains. Two, originating from sporadic human patients, of eight epidemiologically unrelated strains exhibited the identical restriction enzyme patterns. Excepting these two strains, restriciton enzyme analysis of the chromosomal DNA of $L$. monocytogenes serotype $4 \mathrm{~b}$ can discriminate serologically indistinguishable strains.

斎藤章暢 - 徳丸雅一 (埼玉県衛生研究所食品衛生部食品微生物科 埼玉県浦和市上大 久保639-1)

澤田拓士 (日本獣医畜産大学獣医微生物学教室 武蔵野市境南町1-7-1)

本藤 良 (日本獣医畜産大学獣医公衆衛生学教室 武蔵野市境南町1-7-1) 


\section{INTRODUCTION}

Listeria monocytogenes is a gram-positive, short rod-shaped microorganism that has been acknowledged as the cause of listeriosis in human and various animal species. Listeriosis has also been recognized as a food-borne disease, since several major food-borne epidemics have occurred in North America in the 1980s (1-3). Although no epidemic has been verified as being caused by the food-borne listeriosis in Japan (4), L. monocytogenes is widespread in many foods and the environment in Japan (5-7). This indicates that the risk of food-borne listeriosis in Japan is the same as that in North America, therefore, it has become increasingly important to discriminate among $L$. monocytogenes strains for tracing the source of infection and for epidemiological study of listeriosis. Serotyping is commonly used as a discriminating method. Thirteen serotypes have been recognized, but $95 \%$ of the listeriosis cases have been caused by a small number of serovars $(1 / 2 \mathrm{a}$, $1 / 2 b$, or $4 b)(8)$. Molecular epidemiological analyses, such as multilocus enzyme electrophoresis (MEE) $(9,10)$, ribotyping $(11,12)$ and restriction enzyme analysis $(13,14)$, have hardly been used to serologically characterize identical strains from epidemics. We previously reported that six-base restriction enzyems were useful for restriction enzyme analysis of chromosomal DNA of $L$. monocytogenes, and that $L$. monocytogenes strains of serotype $1 / 2$ a could be discriminated among the serologically indistinguishable strains (15). The present study was designed to improve the applicability of restriction enzyme analysis to differentiation of chromosomal DNA of $L$. monocytogenes derived from epidemiologically unrelated strains and that from those related strains of serotype $4 \mathrm{~b}$ which has been the most frequently detected serotype from patients.

\section{MATERIALS AND METHODS}

Bacterial strains: The $L$. monocytogenes strains used in the present study and their sources are listed in Table I. A total of 14 strains of L. monocytogenes serotype $4 \mathrm{~b}$ were examined, including (i) a reference strain (Laboratory for Culture Collection, the Institute of Medical Science, the University of Tokyo, Tokyo), (ii) six wild strains, and (iii) four isolates from different lots of cheese manufactured in the same plant and three from environmental samples obtained in the cheese plant when the source of the cheese contamination was investigated. All strains were identified according to the conventional procedures and serotyped by 
Table I. Listeria monocytogenes serotype $4 \mathrm{~b}$ strains used in the study

\begin{tabular}{lll}
\hline Strain* & Reference & Source \\
\hline IID571 & Reference strain & Sheep \\
H2 & Sporadic clinical isolate & Human \\
H6 & Sporadic clinical isolate & Human \\
SC32 & Epidemiologically unrelated & Poultry \\
Hu80 & Epidemiologically unrelated & Raw hamburger \\
Hu120 & Epidemiologically unrelated & Raw hamburger \\
CH6 & Epidemiologically unrelated & Soft chees \\
CH115 & Different lot from the same plant & Shredded cheese \\
CH188 & Different lot from the same plant & Shredded cheese \\
CH190 & Different lot from the same plant & Shredded cheese \\
CH191 & Different lot from the same plant & Shredded cheese \\
CHF201 & Cheese plant & Environment swab \\
CHF208 & Cheese plant & Environment swab \\
CHF231 & Cheese plant & Drainage \\
\hline
\end{tabular}

*IID, Laboratory for Culture Collection, the Institute of Medical Science, the University of Tokyo.

Dr. M. Terao, Niigata Institute of Public Health and Pollution and Dr. T. Iida, Tokyo Metropolitan Research laboratory of Public Health. Cultures were maintained on nutrient agar slants.

DNA extraction: The DNA isolation procedure of Makino and his coworkers (16) was adopted for L. monocytogenes strains. These strains were inoculated into $1.5 \mathrm{ml}$ of brain heart infusion broth, and incubated with shaking at $35 \mathrm{C}$ for $24 \mathrm{hr}$. The pelleted cells $(20,000 \times \mathrm{g}, 1 \mathrm{~min}, 4 \mathrm{C})$ were suspended in $200 \mu \mathrm{l}$ of TES buffer [1 mM EDTA, $10 \mathrm{mM}$ Tris, $100 \mathrm{mM} \mathrm{NaCl}$ (pH 8.0)]. The cells were lysed by treatment with $10 \mu \mathrm{l}$ of lysozyme (Seikagaku Co., Tokyo) at $10 \mathrm{mg} / \mathrm{ml}$ and $50 \mu \mathrm{l}$ of $\mathrm{N}$ acetylmuramidase SG (Seikagaku) at $1 \mathrm{mg} / \mathrm{ml}$. After incubation (37 C, $30 \mathrm{~min}$ ), $100 \mu \mathrm{l}$ of TES buffer, $50 \mu \mathrm{l}$ of proteinase K (Promega Co., Madison, WI) at 1 $\mathrm{mg} / \mathrm{ml}$ and $50 \mu \mathrm{l}$ of a soidium dodecyl sulfate solution [10\% (wt/vol) in $\mathrm{H}_{2} \mathrm{O}$ ] were added and gently mixed. The lysate was incubated overnight at $55 \mathrm{C}$. The cell lysate was extracted with one volume of TE-saturated phenol [1 mM EDTA, 10 $\mathrm{mM}$ Tris, ( $\mathrm{pH} \mathrm{8.0)]} \mathrm{and} \mathrm{chloroform:isoamylalcohol} \mathrm{(24:1).} \mathrm{The} \mathrm{aqueous} \mathrm{phase} \mathrm{of}$ the lysate was separated, and DNA was precipitated with $1 \mathrm{ml}$ of $99.5 \%$ ethanol. DNA was collected by centrifugation at $20,000 \times \mathrm{g}$ for $3 \mathrm{~min}$ and washed three times in $0.5 \mathrm{ml}$ of $70 \%$ ethanol. The DNA was suspended in $200 \mu \mathrm{l}$ of distilled wa- 
ter and stored at $4 \mathrm{C}$. The concentration and purity of the DNA were determined by UV spectroscopy (Shimadzu UV160 Spectrophotometer, Kyoto).

Restriction enzyme analysis: Ten of six-base restriction enzymes, AatI, BamHI, BamIII, BqIII, EcoRI, KpnI, PstI, SacI, SaII and XbaI, were selected (15). These enzymes were purchased from Toyobo Co, Tokyo. For each restriction digestion, approximately $2 \mu \mathrm{g}$ of DNA was used in a $25 \mu \mathrm{l}$ reaction mixture containing $2.5 \mu \mathrm{l}$ of $\times 10$ restriction buffer, $1 \mu \mathrm{l}$ each of BSA and RNase and 5 to 20 units of enzyme. The reaction mixtures were then incubated at $37 \mathrm{C}$ for one hour. $H$ HindII-digested bacteriophage $\lambda$ DNA was used as the molecular weight standard. DNA fragments were electrophoresed in 1.0\% horizontal agarose gel $(200 \times 150 \times 5 \mathrm{~mm})$ at $30 \mathrm{~mA}$ for $17 \mathrm{hr}$ in $40 \mathrm{mM}$ Tris, $5 \mathrm{mM}$ sodium acetate, $1 \mathrm{mM}$ EDTA (pH 7.8). After electrophoresis, the DNA bands were located under a shortwave UV light and photographed.

\section{RESULTS}

\section{Differences in Restriction Fragment Length Polymorphism}

The classification results for the DNA fingerprint patterns generated from the 10 restriction enzymes were identified. BanIII, PstI and $X b a I$ were particularly well recognizable. Six of the eight $L$. monocytogenes serotype $4 \mathrm{~b}$ strains, which were epidemiologically unrelated, exhibited different restriction enzyme pattern, but two strains $\mathrm{H} 2$ and $\mathrm{H} 6$ derived from human patients exhibited the same restriction enzyme pattern, and two strains, Hu120 derived from raw hamburger and $\mathrm{CH} 115$ derived from cheese, exhibited similar restriction enzyme patterns, after digestion of their DNA with the 10 restriction enzymes. Strain H2 was isolated from the cerebrospinal fluid of a meningitis patient in 1989. Strain H6 was isolated from the cerebrospinal fluid of a newborn in 1995. All of the seven $L$. monocytogenes serotype $4 \mathrm{~b}$ strains, derived from cheese and environmental samples and epidemiologically related, exhibited the same restriction enzyme pattern after digestion of their DNA with the 10 restriction enzymes. Typical results with restriction enzyme $X b a I$ are shown in Fig. 1 . Each restriction enzyme pattern was denoted with a different letter in Table II. 


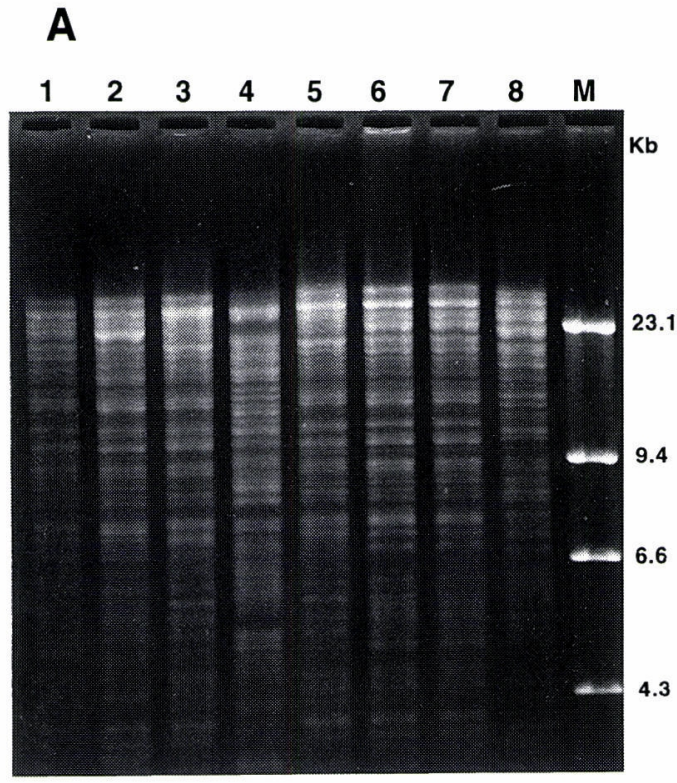

B

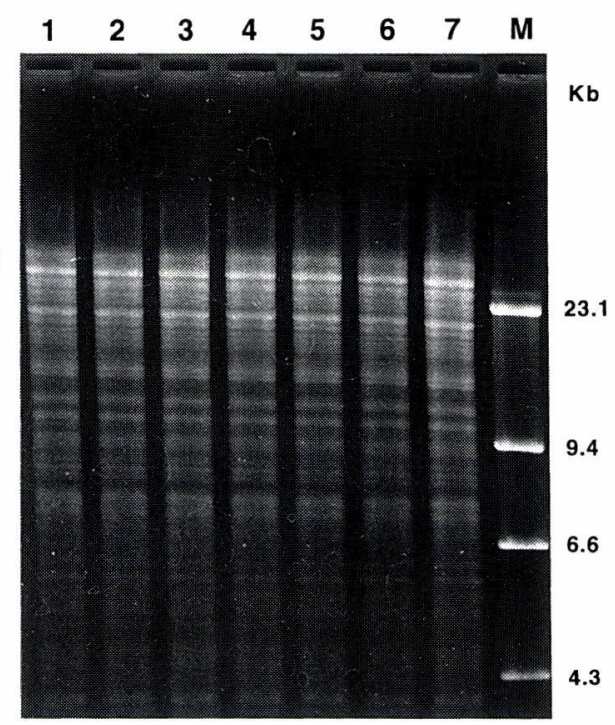

Fig. 1. DNA fingerprint patterns generated from $X b a I$ digests of total DNA. [A] Epidemiologically unrelated strains of L. monocytogenes serotype 4b. [B] Epidemiologically related raw milk strains of $L$. monocytogenes serotype 4b. [A] Lanes: 1 , SC32; 2, Hu80; 3, Hu120; 4, CH6; 5, CH115; 6, H2; 7, H6; 8, IID571; M, molecular weight marker, $\lambda$ DNA digested with HindIII. [B] Lanes: 1, CH115; 2, CH188; 3, CH190; 4, CH191; 5, CHF201; 6, CHF208; 7, CHF231; M, molecular weight marker, $\lambda$ DNA digested with HindIII.

\section{DISCUSSION}

To investigate the epidemiological relationship among $L$. monocytogenes strains, it is important to make experiments with epidemiologically related strains. In this study, we examined $L$. monocytogenes strains derived from epidemiologically related cheese and environmental samples; seven strains of $L$. monocytogenes serotype $4 \mathrm{~b}$ were isolated from four different lots of cheese, two processing environments, and one drainage at the same cheese plant when investigating the cause of cheese contamination. The source of contaminant was not ascertained, but the present study supported the finding that L. monocytogenes 


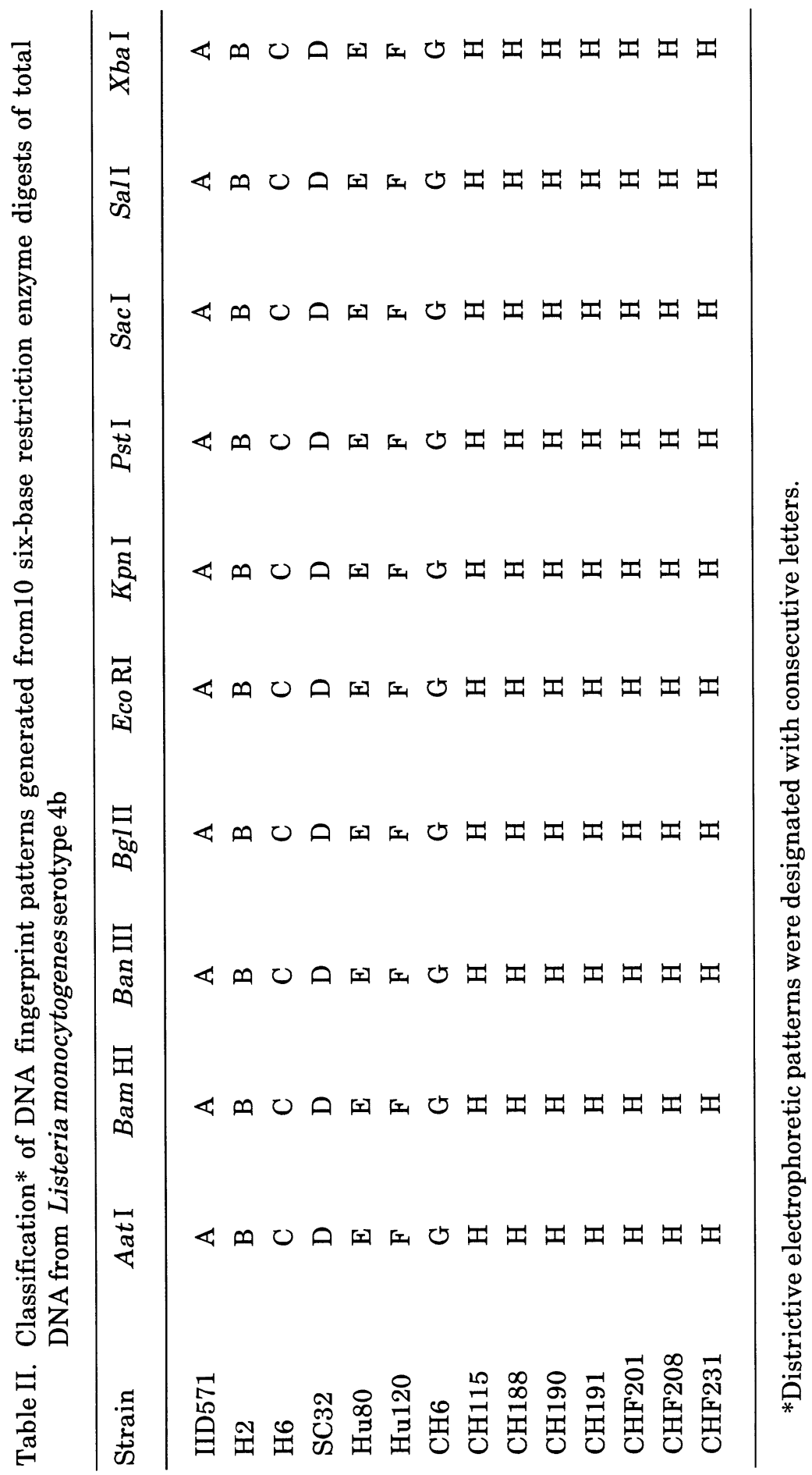


serotype $4 \mathrm{~b}$ strains originating from the contaminated cheese were widespread and prevalent for a long time.

Strains $\mathrm{H} 2$ and $\mathrm{H} 6$ exhibited the same restriction enzyme patterns of DNA. Although we have no detailed information about these two strains, there was no particular relationship between the lives of the two patients' families and there was a 6-year difference between the times when the two strains were isolated.

We previously reported that the $L$. monocytogenes serotype $1 / 2$ a strains were discriminated by restriction enzyme analysis of chromosomal DNA with sixbase restriction enzymes (BanIII, PstI and XbaI were particularly wellrecognizable) (15). In the present study, epidemiologically unrelated $L$. monocytogenes strains of serotype $4 \mathrm{~b}$, which is the most common serotype derived from the patients, also exhibited different restriction enzyme patterns except two strains with 10 of the six-base restriction enzymes and the above three restriction enzyems, BanIII, PstI and XbaI, were particularly well recognizable. Thus, we confirmed that restriction enzyme analysis of $L$. monocytogenes chromosomal DNA using the six-base restriction enzymes, especially BanIII, PstI and XbaI, could also be useful for differentiation of serologically indistinguishable strains of L. monocytogenes serotype $4 \mathrm{~b}$.

\section{ACKNOWLEDGEMENTS}

We thank Dr. Michinori Terao, the Niigata Institute of Public Health and Polution and Dr. Takashi Iida, the Tokyo Metropolitan Research Laboratory of Public Health, for the serotyping of $L$. monocytogenes strains used in this study, and Mr. Susumu Funahashi, Higashi-Matsuyama Health Center, for collecting the materials.

\section{REFERENCES}

1. Fleming, D. W., Cochi, S. L., MacDonald, K. L., Brondum, J., Hayes, P. S., Plikaytis, B. D., Holmes, M. B., Audurier, A., Broome, C. V. and Reingold, A. L. (1985): Pasteurized milk as a vehicle of infection in an outbreak of listeriosis. N. Engl. J. Med., 312, 404-407.

2. Linnan, M. J., Mascola, L., Lou, X. D., Goulet, V., May, S., Salmainen, C., Hind, D. W., Yonekura, M. L., Hayes, P., Weaver, R., Audurier, A., 
Plilkaytis, B. D., Fannin, S. L., Kleks, A. and Broome, C. V. (1988): Epidemic listeriosis associated with Mexican-style cheese. N. Engl. J. Med., 319, 823-828.

3. Schlech, W. F., Lavigne, P. M., Bortolussi, R. A., Allen, A. C., Haldene, E. V., Wort, A. J., Martin, R. S., Hightower, A. W., Jhonson, S. E., King, S. H., Nicholls, E. S. and Broome, C. V. (1983): Epidemic listeriosis-evidence for transmission by food. N. Engl. J. Med., 308, 203-206.

4. Maruyama, T. (1994): Current status of foodborne listeriosis. Food Sanitation Res., 44, 67-83 (in Japanese).

5. Mizutani, H., Iida, T. and Maruyama, T. (1990): Isolation of Listeria monocytogenes from intestinal contents and carcasses of cows and pigs in an abattoir. J. Jpn. Vet. Med. Assoc., 43, 602-605 (in Japanese).

6. Saito, A., Itaya, T., Aoki, A., Ando, K., Masaki, H. and Tokumaru, Y. (1993): The incidence of Listeria spp. in commercial raw hamburgers and their bacteriological safety following cooking. Jpn. J. Food Microbiol., 10, 121-125 (in Japanese).

7. Saito, A., Tokumaru, Y., Masaki, H., Itaya, T. and Aoki, A. (1991): Evaluation of enrichment and plating media for the isolation of Listeria monocytogenes from raw milk and the state of contamination of raw milk by Listeria. J. Jpn. Vet. Med. Assoc., 44, 378-383 (in Japanese).

8. Terao, M. (1991): Human listeriosis in Japan. J. Vet. Med., 44, 9 -12 (in Japanese).

9. Bibb, W. F., Gellin, B. G., Weaver, R., Schwartz, B., Plikaytis, B. D., Reeves, M. W., Pinner, R. W. and Broome, C. V. (1990): Analysis of clinical and foodborne isolates of Listeria monocytogenes in the United States by multilocus enzyme electrophoresis and application of the method to epidemiologic investigation. Appl. Environ. Microbiol., 56, 2133-2141.

10. Piffaretti, J.-C., Krressebuch, H., Aescbacher, M., Billi, J., Bannerman, E., Musser, J. M., Selander, R. K. and Rocourt, J. (1989): Genetic characterization of clones of the bacterium Listeria monocytogenes causing epidemic disease. Proc. Natl. Acad. Sci., 86, 3818-3822.

11. Graves, L. M., Swaminathan, B., Reeves, M. W. and Wenger, J. (1991): Ribosomal DNA fingerprint of Listeria monocytogenes using a digoxigeninlabeled DNA probe. Eur. J. Epidemiol., 7, 77-82.

12. Jacquet, C., Bille, J. and Rocourt, J. (1992): Typing of Listeria monocytogenes by restriction polymorphism of the ribosomal ribonucleic acid gene region. Zbl. Bakteriol., 276, 356-365.

13. Carriere, C. H., Allardet-Servent, A., Bourg, G., Auderier, A. and Ramuz, M. (1991): DNA polymorphism in strains of Listeria monocytogenes. J. Clin. Microbiol., 29, 1351-1355.

14. Nocera, D., Bannerman, E., Rocourt, J., Jaton-Ogay, K. and Bille, J. (1990): Characterization by DNA restriction endonuclease analysis of Listeria monocytogenes strains related to the Swiss epidemic of listeriosis. J. Clin. Microbiol., 28, 2259-2263. 
15. Saito, A. and Hondo, R. (1996): Genome variation among Listeria monocytogenes isolates derived from epidemiologically related raw milk and other strains. J. Food Prot., 59, 998-1002.

16. Makino, S., Okada, Y., Maruyama, T., Ishikawa, K., Takahashi, T., Nakamura, M., Ezaki, T. and Morita, H. (1994): Direct and rapid detection of Erysipelothrix rhusiopathiae DNA in animals by PCR. J. Clin. Microbiol., $32,1526-1531$. 